\title{
Rapid Estrogen Signaling in the Brain
}

\author{
Limor Raz $^{\mathrm{a}}$ Mohammad M. Khan ${ }^{\mathrm{a}}$ Virendra B. Mahesh ${ }^{\mathrm{a}}$ Ratna K. Vadlamudi ${ }^{\mathrm{b}}$ \\ Darrell W. Brann ${ }^{\text {a }}$ \\ ${ }^{a}$ Institute of Molecular Medicine and Genetics, Medical College of Georgia, Augusta, Ga., and ${ }^{b}$ Department of \\ Obstetrics and Gynecology, University of Texas Health Science Center at San Antonio, San Antonio, Tex., USA
}

\section{Key Words}

Estradiol, nongenomic • Membrane - Estrogen receptor •

Neuron $\cdot$ Kinase $\cdot$ GPR30 synapse

\begin{abstract}
Estrogen has multiple actions in the brain to modulate homeostasis, synaptic plasticity/cognition and neuroprotection. While many of these actions undoubtedly involve mediation via the classical genomic mechanism of regulation of transcription of genes via estrogen nuclear receptors, there has been growing interest in the rapid nongenomic effects of estrogen and the role they may play in the neural actions of estrogen. In this review, we will focus on these rapid nongenomic actions of estrogen in the brain and discuss the potential physiological significance of these actions. The evidence for rapid estrogen regulation of cell signaling pathways, including calcium, ion channel and kinase signaling pathways in the brain will be reviewed, as will evidence derived from plasma-membrane impermeable estrogenpeptide conjugates in the regulation of these cell signaling pathways. Evidence supporting classical and nonclassical estrogen receptor localization to the plasma membrane of neurons will also be reviewed, including the putative new membrane estrogen G-protein-coupled receptor, GPR30. Precisely how membrane estrogen receptors couple to kinase signaling pathways is unclear, but we will discuss the latest findings on estrogen receptor-interacting scaffold proteins, such as MNAR/PELP1, striatin and p130Cas, which are capable of linking estrogen receptors and kinases such
\end{abstract}

as Src and PI3K, to potentially mediate estrogen-induced kinase signaling. Finally, we will review the growing evidence that rapid membrane-mediated effects of estrogen play an important physiological role in the neural actions of estrogen in the brain, including estrogen feedback control and modulation of homeostasis, regulation of synaptic plasticity/cognition, and estrogen-mediated neuroprotection.

Copyright $\odot 2008$ S. Karger AG, Basel

\section{Introduction}

Estrogen (17 $\beta$-estradiol) exerts regulatory effects in a variety of tissues in the body, including the brain, breast, cardiovascular system, uterus and bone [1-7]. Its effects in the brain are of considerable importance, as estrogen can modulate homeostasis through its neuroendocrine feedback effects, as well as exert neuroprotective and cognitive-enhancing effects [1-11]. The brain regulatory effects of estrogen have been of significant interest due to evidence that estrogen may delay onset or ameliorate the severity of several neurological disorders, such as Alzheimer's disease, Parkinson's disease, and stroke [1, 813], although controversies do exist in this area as exemplified by the controversial WHI results [for review, see 1]. Understanding how estrogen signals in the brain is critical to understanding how it exerts its purported beneficial effects. This review will focus on the rapid, nongenomic signaling effects of estrogen, which is a fast-emerging area.

\section{KARGER \\ Fax +41613061234 \\ E-Mail karger@karger.ch}

www.karger.com
(C) 2008 S. Karger AG, Base

$1424-862 X / 08 / 0163-0140 \$ 24.50 / 0$

Accessible online at:

www.karger.com/nsg
Darrell W. Brann, PhD

Regents' Professor and Director of the Graduate Program in Neuroscience Institute of Molecular Medicine and Genetics, Medical College of Georgia 1120 15th Street, Augusta, GA 30912 (USA)

Tel. +1 706721 7779, Fax +1 706721 8685, E-Mail dbrann@mcg.edu 
Classically, estrogen has been thought to exert its effects via a genomic mechanism of action involving binding of estrogen to nuclear estrogen receptors and subsequent regulation of transcription. The genomic mechanism of action typically takes several hours for the effect to be manifested due to the time needed for transcription and translation of estrogen-regulated genes [14]. However, a growing body of evidence has emerged, which describes rapid estrogen effects that occur within minutes and thus cannot be attributed to a genomic mechanism of action. These rapid effects have thus been designated as 'nongenomic' effects of estrogen [3, 15-19]. A search in PubMed with the keywords 'estrogen and nongenomic' yields over 334 published papers, with $94 \%$ of these papers being published within the last 10 years. Thus, this area has seen an explosion of interest in the past decade, and represents one of the fastest emerging areas in the field of estrogen research. In particular, in the past few years new information has emerged on the types of estrogen receptors at the plasma membrane, targeting of estrogen receptors to the membrane, and scaffold proteins that may link estrogen receptors to kinase signaling pathways in the brain. These areas will be reviewed with interpretations and future directions for the field discussed. The evidence for functional significance of rapid estrogen signaling in the brain will also be reviewed and discussed, as new data has also emerged on this important topic. It should be mentioned that there is also evidence of ligandindependent activation of estrogen receptors which involves crosstalk with peptide growth factors. This, however, is outside the focus of this review, and the reader is referred to previous excellent reviews on this subject for further elaboration and discussion [20,21]. It is hoped that by gaining a more thorough understanding of estrogen's effects on the brain and a better grasp of the signaling cascade involved, we will gain new insights that lead to better diagnostic tools and improved therapeutics in humans.

\section{Evidence of Rapid Estrogen Signaling in the Brain}

\section{Electrophysiological Activity}

Reports of rapid estrogen (17 $\beta$-estradiol) effects in the brain first began to appear in the literature over 40 years ago, when it was observed that estrogen rapidly modulated hypothalamic electrical activity [22-26]. The latency of the estrogen effects was within minutes, and typically two types of effects were observed on hypothalamic neurons - some units had a decreased firing rate that lasted up to $150 \mathrm{~min}$, whereas other units responded with a transitory increase in firing rates. The remaining units were unresponsive to estradiol [24]. Kelly et al. [26-29] showed that neurons from several hypothalamic regions displayed rapid electrophysiological responses to estrogen, including preoptic, arcuate and parvicellular ventromedial hypothalamic neurons. Further studies extended the rapid estrogen effects on electrophysiological responses to other regions of the brain, including the amygdala, cerebellum, and hippocampus [28, 30-33]. These early observations set the stage for subsequent studies on the mechanisms underlying the rapid effects of estrogen in the brain. Along these lines, subsequent work revealed that estrogen rapidly modulated several cell signaling pathways in neurons (and non-neuronal cells), including kinases, ion channels and second messengers. The evidence supporting the regulation of these signaling pathways by estrogen is discussed below.

\section{Kinases}

ERKs

There are now many studies in the literature demonstrating that estrogen rapidly activates multiple kinases in various types of brain cells within minutes, including extracellular signal-regulated kinases (ERKs), Akt and cAMP response element binding protein (CREB). The first report of rapid estrogen regulation of ERK1/2 in neuronal cells came from the study of Watters et al. [34] in 1997, which showed that estrogen enhanced ERK1/2 phosphorylation in human neuroblastoma cells within 5-10 min. Subsequent in vitro studies by many laboratories confirmed and extended the rapid estrogen regulatory ERK effect to other species and other neuronal populations such as rat cerebral cortical explants $[35,36]$, rat cortical neurons [37, 38], and rat and mouse hippocampal neurons $[39,40]$. In vivo confirmation of the rapid estrogen effect on ERK phosphorylation has also been demonstrated. Kuroki et al. [41] showed that estrogen administered intracerebroventrically into the lateral ventricle of rats enhanced ERK phosphorylation within $5 \mathrm{~min}$ in the hippocampal CA1 region and dentate gyrus, while Bryant et al. [42] demonstrated that subcutaneous injection of estrogen in rats increased ERK phosphorylation in many regions of the brain at 20 min after estrogen administration.

\section{Akt/CREB}

In addition to regulation of ERK activation, estrogen has been shown to rapidly enhance phosphorylation of Akt and CREB in cortical neurons and explants [37, 38, 43-45] and hippocampal neurons [40]. Furthermore, 
Mannella and Brinton [37] have reported that estrogen induces phosphorylation of ERK and Akt in the same population of cortical neurons in vitro, suggesting a possible unified mechanism of action for estrogen. Further work supported this possibility as it was shown that estrogen receptors interact with the PI3K P85 regulatory subunit in cortical neurons, and that pretreatment with a PI3K inhibitor blocked estrogen-induced activation of pAkt and pERK [37].

\section{Calcium and Ion Channels}

In addition to regulation of kinase activation, estrogen has been shown to rapidly regulate intracellular calcium levels in neurons. For instance, patch clamp experiments show that estrogen can reduce $\mathrm{Ca}^{2+}$ currents following estrogen influx in rat neostriatal neurons via a nongenomic mechanism [46]. Additionally, Huang et al. [47] used fluorescent $\mathrm{Ca}^{2+}$ probes to show that estrogen rapidly attenuates glutamate-induced $\mathrm{Ca}^{2+}$ overload in rat primary hippocampal neurons. In contrast, under basal conditions, estrogen acts to increase intracellular calcium concentrations in midbrain neurons [48] and in the cytoplasm, dendrites and nucleus of rat hippocampal neurons, which seems important for changes in hippocampal dendritic spine protein regulation by estrogen [49]. The calcium changes also may be important for estrogen-induced kinase changes. Along these lines, Wu et al. [40] showed that estrogen induced a rapid rise of intracellular $\mathrm{Ca}^{2+}$ concentration within minutes of exposure in rat hippocampal neurons in vitro, which was blocked by an L-type $\mathrm{Ca}^{2+}$ channel antagonist. If the Ltype $\mathrm{Ca}^{2+}$ channels are inhibited by an inhibitor, it results in a loss of estrogen activation of Src/ERK and CREB signaling pathways in hippocampal neurons. Estrogen can also rapidly modulate $\mathrm{K}^{+}$channels in hypothalamic (POMC, dopamine, GABA, GnRH) neurons that are involved in many homeostatic functions [50]. Kelly et al. [51] have proposed that the estrogen regulation of $\mathrm{K}^{+}$ channels in the brain involves G-coupled protein receptors and cAMP-dependent phosphorylation. Thus, estrogen can exert rapid regulation of calcium and potassium channels in neurons from various regions of the brain, and these effects may help mediate estrogen actions in the brain. The evidence for a physiologically important role of nongenomic signaling in estrogen actions in the brain is discussed below.

\section{Functional Significance of Rapid Estrogen Signaling}

There is now increasing evidence that the rapid effects of estrogen may be important for manifestation of sev- eral of its key biological actions in the brain, such as neuroprotection, plasticity/cognition, and homeostasis. Along these lines, in vitro studies by several laboratories have shown that the rapid activation of ERKs by estrogen is critical for its neuroprotective effects, as administration of a MEK inhibitor blocks the neuroprotective effects of estrogen in neurons [40, 52-54]. Furthermore, in vivo studies by Jover-Mengual et al. [55] suggest that estrogen-induced ERK activation in the CA1 region after global cerebral ischemia is critical for its neuroprotective effects, as treatment with the MEK inhibitor (PD98059) blocked estrogen-induced ERK activation and estrogen neuroprotection in the hippocampus. Likewise, a role for the serine kinase Akt in estrogen neuroprotection has been implicated, as estrogen rapidly upregulated Akt activation in cortical neurons in vitro [43], and in the hippocampus in vivo following cerebral ischemia [56], while treatment with a PI3K inhibitor attenuated the neuroprotective effects of estrogen both in vitro and in vivo. Estrogen activation of kinase signaling may also be important for the synaptic plasticity effects of estrogen, as administration of kinase inhibitors (ERK or PKA pathway inhibitors) has been shown to block estrogen-induced enhancement of neurite outgrowth [57], dendritic spinogenesis [58] and synapse formation [59].

There is also growing evidence that rapid nongenomic effects of estrogen play a role in homeostatic neuroendocrine feedback control exerted by estrogen. For instance, Gidewell-Kenney et al. [60] developed a 'knockin' mouse expressing a mutant form of ER $\alpha$ with ablated ERE-dependent but intact ERE-independent signaling. They then bred the knockin mouse onto the ER $\alpha$-null background and studied the effects on female neuroendocrine feedback control and reproductive physiology. They found that estrogen negative feedback signaling on luteinizing hormone signaling was preserved in the knockin mice, but that estrous cyclicity, spontaneous ovulation and positive feedback signaling were lost. These results suggest that nongenomic estrogen signaling may mediate negative feedback of estrogen, but is not required or sufficient to mediate positive feedback control and maintain estrous cyclicity and ovulation. A similar result was demonstrated in male animals (e.g. that nongenomic signaling was important for the negative feedback effects of estrogen on gonadotropin secretion, but was not required or sufficient for expression of sexual behavior in males) [61]. These studies using mutant ERE knockin $\mathrm{ER} \alpha-/$ - mice provide evidence of a significant physiological role of nongenomic estrogen signaling in the brain. The studies are well suited (in mice) to show a required 
role of ERE-independent estrogen signaling. However, they are not well suited to show crosstalk between the nongenomic and genomic actions of estrogen that may contribute to mediation of estrogen functions in the brain. This issue will be discussed in greater detail in subsequent sections below. Thus, while progress has been made, clearly further studies are needed using multiple approaches to continue to enhance our understanding of the physiological significance of nongenomic estrogen signaling in the brain.

\section{Membrane Estrogen Receptor Mediation of Rapid Estrogen Effects in the Brain}

\section{Estrogen-BSA and Estrogen-Dendrimer Conjugates}

The rapid effects of estrogen on calcium and ion channel signaling, as well as kinase activation, suggest a potential membrane receptor-mediated effect of estrogen. One piece of evidence supporting a membrane receptormediated mechanism is the use of membrane impermeable conjugates of estrogen, such as estrogen-BSA and estrogen-dendrimers. Similar to estrogen, estrogen-BSA was shown to rapidly enhance phosphorylation of ERK1/2 in the human neuroblastoma SK-N-SHR cells [34], in rat hypothalamic neurons in vitro [62], and in the rat hippocampus in vivo [41]. Estrogen-BSA conjugates have also been shown to rapidly enhance protein kinase A activation in hippocampal neurons [63], increase intracellular calcium levels within minutes in both astrocytes and neurons $[64,65]$, and to rapidly modulate potassium channel activation in hypothalamic neurons [66]. Nevertheless, it should be pointed out that there has been some criticism of estrogen-BSA conjugates, in that some estrogen $(3-5 \%)$ can be found in the free unconjugated form in commercially available estrogen-BSA conjugates [67]. For this reason, it is advisable that the estrogen-BSA be subjected to filtration in order to remove free estrogen, and that studies that fail to perform the filtration should be interpreted cautiously. Stevis et al. [67] reported that estrogen-BSA did not bind ER $\alpha$ or ER $\beta$ in binding studies; however, a subsequent study demonstrated that estrogen-BSA indeed binds to purified estrogen receptors in vitro and to membrane estrogen receptors in intact cells, albeit at a slower rate than estrogen [68].

Recently, a new class of estrogen conjugates has been developed - the estrogen dendrimers (EDCs) [69]. EDCs are constructed by the attachment of an estrogen through the 17-position, to an abiological macromolecule, a poly(amido)amine (PAMAM) dendrimer, via a hydrolyt-

Rapid Estrogen Signaling in the Brain ically stable linkage. The PAMAM dendrimer's core provide flexibility in macromolecule size and surface charge, and produces conjugates that can be further characterized with fluorophores to trace the cellular distribution of the EDCs. While not yet tested in neurons, EDCs have been shown in MCF-7 breast cancer cells to bind to the membrane and rapidly enhance ERK, Shc and Src phosphorylation, yet are very ineffective in enhancing transcription $(10,000$-fold less potent than estradiol in genomic actions) [69]. Similarly, estrogen-BSA has been reported not to increase transcription of an ERE-based reporter gene in human neuroblastoma cells, further suggesting that estrogen conjugates do not enter the cell and are unable to activate nuclear estrogen receptors and genomic signaling [70, 71]. Rai et al. [72] also showed in breast cancer cells that transfection of a modified, membrane-targeted estrogen receptor that lacked a nuclear localization sequence, led to membrane localization of the modified estrogen receptor and that the membrane-targeted estrogen receptor failed to regulate estrogen-responsive genes that are upregulated by wild-type nuclear estrogen receptors. However, Pfaff and coworkers [71, 73, 74] have provided evidence that estrogen-BSA may act to potentiate genomic actions of estrogen using a twopulse paradigm (first pulse $=$ estrogen-BSA, and second pulse = estrogen). In their study, they showed that the first pulse estrogen-BSA can enhance transcription from a consensus ERE-driven luciferase gene in neuroblastoma cells induced by a second pulse of estrogen. The potentiation effect of estrogen-BSA on estrogen genomic actions was blocked by PKA or PKC inhibitors, suggesting that the rapid membrane signaling induced by estrogenBSA exerts crosstalk with the nucleus that enhances the genomic effects of estrogen. Further work showed that this two pulse estrogen-BSA/estrogen paradigm enhanced lordosis sexual behavior of female rats [74], demonstrating that the nongenomic/genomic crosstalk by estrogen could enhance a functionally relevant endpoint. Taken as a whole, the estrogen conjugate data suggest that rapid signaling effects of estrogen involve mediation via a membrane estrogen receptor. The subsequent sections of this review will examine the evidence supporting membrane localization of estrogen receptors $(\mathrm{ER} \alpha, \mathrm{ER} \beta$, ER-X, GPR30) in neurons and discuss the role each may play in mediating rapid estrogen effects in the brain.

\section{Evidence of Estrogen Receptor Localization to the} Plasma Membrane

Ultrastructural electron-microscopic studies have provided direct evidence of extranuclear localization of 

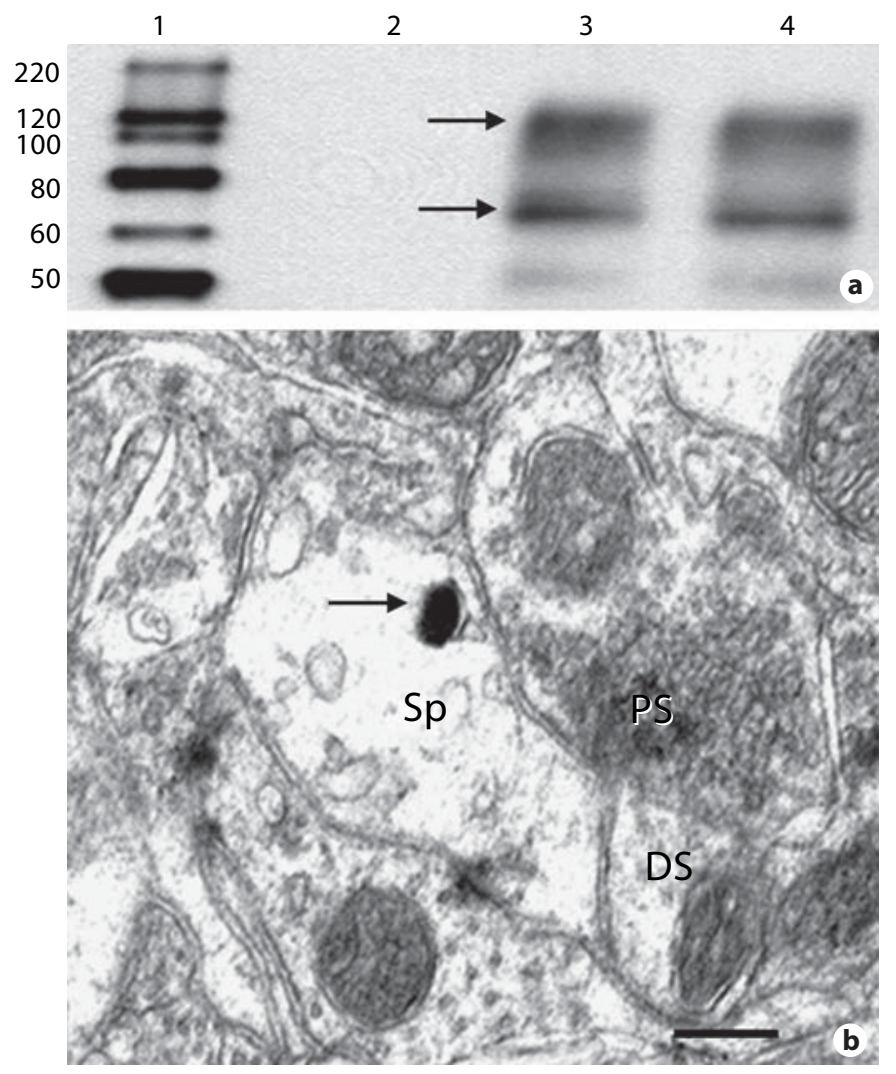

Fig. 1. a Expression of estrogen receptor alpha (ER $\alpha)$ on the membrane surface in 4-14 days in vitro (DIV) cultured rat cortical neurons. Surface labeling of ER $\alpha$ was performed by biotinylation method using a commercially available kit. Lane 1 shows the positions of various markers, lane 2 represents total cell lysate before biotinylation, while lanes 3-4 represent total cell lysates after biotinylation of surface proteins from 4 DIV (lane 3) and 14 DIV cultured neurons (lane 4). Total cell lysate from biotinylated (lanes 3,4) as well as nonbiotinylated (lane 2) samples were incubated with immobilized 'NeurtrAvidin' agarose gel for $1 \mathrm{~h}$ at room temperature and the bound proteins were eluted using SDSDTT sample buffer. Two ER $\alpha$ bands (arrows) were detected - a dimer $(\sim 120 \mathrm{kDa})$ and a monomer $(\sim 65 \mathrm{kDa})$, demonstrating that ER $\alpha$ is localized in the plasma membrane of rat cortical neurons. b Electron micrograph showing ER $\alpha$-reactive gold particle (arrow) in the dendritic spine from the prefrontal cortex of an adult female rat brain. $\mathrm{Sp}=$ Postsynaptic dendritic spine; DS = dendritic shaft; PS = presynaptic terminal. Scale bar $=200 \mathrm{~nm}$.

estrogen receptors in the brain [75-77]. Milner et al. [75] performed ultrastructural studies of $\mathrm{ER} \alpha$ localization in the rat hippocampal formation and demonstrated that $\mathrm{ER} \alpha$, in addition to nuclear localization, is found in cytoplasm and plasma membrane of neurons, and in unmyelinated axons and axon terminals. Furthermore, approximately $25 \%$ of $\mathrm{ER} \alpha$ is localized in dendritic spines, often associated with spine apparati and/or polyribosomes, suggesting it may act to regulate calcium availability, local protein translation, and synaptic growth. Figure 1 shows a similar observation in the rat cerebral cortex, in that electron microscopy studies by our laboratory demonstrate $\mathrm{ER} \alpha$ immunolocalization in dendritic spines in the rat cerebral cortex. Moreover, biotinylation of cultured rat cortical neuron membrane proteins, followed by pull down with avidin bead column and subsequent Western blot analysis for $\mathrm{ER} \alpha$, showed that $\mathrm{ER} \alpha$ is present in the plasma membrane of rat cortical neurons (fig. 1). Additional work by Romeo et al. [77] showed that there is a $114 \%$ increase in $\mathrm{ER} \alpha$ in hippocampal dendritic spines in proestrus female rats as compared to diestrus female rats and male rats. Thus, there appears to be some cycle-related fluctuations in ER $\alpha$ in dendritic spines in the hippocampus. Fluorescent-tagged estrogen-BSA conjugates and transfection of GFP-tagged ER $\alpha$ constructs have also been used to determine membrane or subcellular localization of estrogen receptors in neurons in vitro. Using Western blot and estrogen-horseradish protein-FITC or estrogen-BSA-FITC conjugates, Marin et al. $[78,79]$ showed plasma membrane localization of ER $\alpha$ in SN56 septal-derived cholinergic neurons, and that the estrogen conjugates protected the cells against A-beta toxicity as effectively as estrogen. Xu et al. [80] transfected GFP-tagged human ER $\alpha$ in rat cortical neurons in vitro and determined its subcellular localization. The studies revealed that there was localization of the GFP-tagged human ER $\alpha$ in neurites of the cortical neurons and that the ER $\alpha$ appears to be directed to the neurites directly from its site of translation and not from nuclear stores. Furthermore, as shown and discussed in figure 1, biotinylated membrane protein studies also support localization of ER $\alpha$ at the plasma membrane of rat cortical neurons. Finally, ultrastructural studies have also demonstrated that the other ER subtype, ER $\beta$ is also localized at extranuclear sites such as cytoplasm, plasma membrane, dendritic spines, axons and axon terminals in the rat hippocampus [76]. Thus, ER $\beta$ could also have a role in mediating nongenomic actions of estrogen in the brain. We should also mention that a novel plasma-membrane-associated estrogen receptor called ER-X has been proposed as well in neurons of the brain, but attempts to clone it have so far been unsuccessful [81].

\section{Palmitoylation - A Key Factor in Localization of ER at the Plasma Membrane?}

It is unclear how estrogen receptors are targeted to the plasma membrane. However, recent work in non-neuro- 
nal cells has implicated palmitoylation of the estrogen receptor as an important mechanism for targeting ER to the plasma membrane [82-84]. Palmitoylation is a posttranslational modification that consists of the addition of a 16-carbon fatty acid, palmitate, to a cysteine residue through the creation of a thioester link. Work from several laboratories has shown that palmitoylation occurs on residues in the $\mathrm{E}$ domain (ligand-binding domain) of $\mathrm{ER} \alpha$ and $\mathrm{ER} \beta$, and that mutation of these key residues in the $\mathrm{E}$ domain significantly reduces ER localization to the plasma membrane and decreases ERK and Akt activation [82-84]. Furthermore, administration of a pamitoylacyltransferase inhibitor, 2-bromo-hexadecanoic acid, has been shown to attenuate ER localization to the plasma membrane and ERK activation in HeLa cervix cancer cells [82]. These studies suggest that palmitoylation of ER may help target ER to the plasma membrane. Correlative studies in the brain on the role of palmitoylation in ER subcellular targeting and nongenomic signaling are currently lacking. Studies to address this issue and determine how palmitoylation of the ER might be regulated are needed.

\section{Estrogen Rapid Signaling in Estrogen Receptor}

Knockout Mice

One approach to determine the role of classical estrogen receptors in mediating rapid signaling effects of estrogen in the brain is to utilize mutant mice with one or both classical ERs knocked out. Using this approach, Chaban and Micevych [85] demonstrated that rapid estrogen inhibition of ATP-induced calcium signaling in dorsal root ganglion neurons is blocked by an ER antagonist, and that the effect of estrogen on calcium signaling is lost in ER $\alpha$ knockout mice. Herbison and colleagues [86] have demonstrated that estrogen-induced phosphoCREB in hypothalamic GnRH neurons is preserved in $\mathrm{ER} \alpha$ knockout mice, but lost in ER $\beta$ knockout mice. Likewise, other studies also show the loss of rapid estrogen-induced phospho-CREB responses in ER $\beta$ knockout mice, particularly in areas where ER $\beta$ is densely localized [87]. With regard to ERK regulation, there are contradicting reports on the estrogen regulation of phospho-ERKs in ER-knockout mice. Singh et al. [88] reported that estrogen-induced phosphorylation of ERKs was not lost in cortical neurons from ER $\alpha$ knockout mice, suggesting that ER $\alpha$ may not mediate the rapid phospho-ERK-enhancing effects of estrogen. In contrast, Abraham et al. [87] reported that rapid estrogen induction of phosphorylation of ERKs in the medial preoptic nucleus was lost in both $\mathrm{ER} \alpha$ and $\mathrm{ER} \beta$ knockout mice, suggesting that both ER $\alpha$ and ER $\beta$ may mediate the ERK regulatory effect of estrogen. Finally, estrogen can also rapidly induce c-Fos protein in the brain, an effect which has been shown to be lost in double $\mathrm{ER} \alpha / \beta$ knockout mice in the ventral medial nucleus, preoptic area, granule accessory layer of the olfactory bulb, and pyramidal layer of the CA3 hippocampus [89]. Interestingly, two regions did not show a loss of estrogen induction of $\mathrm{c}$-Fos in the double ER $\alpha / \beta$ mice: the olivary pretectal nucleus and cingulate cortex. As a whole, the ER knockout mice results shed some light on involvement of ER $\alpha$ or ER $\beta$ in rapid signaling effects of estrogen in the brain. Additionally, they suggest that the role of ER $\alpha$ or ER $\beta$ in rapid estrogen signaling effects may differ from one brain region to another, and results in one region cannot be immediately extrapolated to another region or another kinase.

\section{GPR30 - A Novel Membrane Estrogen Receptor?}

Recent interest in the field of rapid estrogen signaling has focused on a novel seven transmembrane domain G-protein-coupled receptor called GPR30, which has recently been proposed to function as a membrane estrogen receptor [90-94]. GPR30 was first identified and cloned by Carmechi et al. [90] in 1997. Using a differential cDNA library screening technique, the investigators identified GPR30 as a differentially expressed gene in a screen of genes from an ER-positive breast cancer cell line (MCF-7) versus an ER-negative breast cancer cell line (MDA-MB361). Most studies show that GPR30 is localized in the plasma membrane of cells, but an endoplasmic reticulum localization for GPR30 has also been reported [91-94]. Additionally, electron microscopy by our laboratory and others has confirmed that GPR30 is localized in the plasma membrane $[95,96]$ and endoplasmic reticulum $[95]$ of neurons in the brain. It should be mentioned that seventransmembrane domain receptors are known to be retained in the endoplasmic reticulum as a consequence of carbohydrate processing, disulfide bond exchange, and proteolytic editing, which may explain the observation of GPR30 localization in the endoplasmic reticulum. Alternatively, GPR30 may have a functional role in the endoplasmic reticulum, which remains to be determined.

Radioreceptor assays have shown that membrane expression of GPR30 in human ER-negative breast SKBR3 cancer cells is associated with high-affinity, saturable, low-capacity binding for estrogen $[93,94]$. Treatment of the SKBR3 cells with GPR30 siRNAs significantly reduced GPR30 mRNA and protein and resulted in an $80 \%$ 
decrease in estrogen binding [93, 94]. Further work has implicated GPR30 as having a role in mediating rapid estrogen modulation of calcium, cAMP, and ERK signaling in human breast cancer and liver cell lines [91-94]. However, there are a number of controversies surrounding the putative role of GPR30 as an estrogen receptor involved in physiological estrogen signaling. For instance, even though ER-negative SKBR3 breast cancer cells have abundant GPR30 expression, they have an extremely low estrogen binding interaction, with only modest generation of cAMP observed in cells transfected with GPR30 [94]. Additionally, Pedram et al. [97] demonstrated that GPR30 siRNA knockdown in MCF-7 breast cancer cells did not affect estrogen rapid signaling to cAMP, ERK, PI3K, calcium or cell survival, while ER $\alpha$ siRNA knockdown prevented the rapid signaling and survival effects of estrogen in MCF-7 cells. Furthermore, the preponderance of work in the field has been performed in cell lines, and studies in vivo are lacking. Finally, few studies assessed functional endpoints, so the functional significance of the purported GPR30-mediated signaling effects remains unclear.

With respect to the brain, information has now begun to appear concerning GPR30 distribution in various brain regions in rodents. Work from several laboratories has shown that GPR30 is expressed in many regions of the brain with high expression noted in the hypothalamic-pituitary axis, hippocampus, brainstem autonomic nuclei, cortex and striatum $[95,96,98]$. Additionally, a putative GPR30 selective agonist, G-1, has been shown to increase intracellular calcium concentrations in cultured hypothalamic neurons [98], but unfortunately no functionally relevant endpoints were assessed in the study to determine the physiological significance of the observation. To date, there are no studies establishing a physiological role for GPR30 in estrogen signaling in the brain. Studies using GPR30 knockout mice may help address this issue and clarify the role of GPR30 in estrogen actions and signaling in the brain, as well as in other estrogen-target tissues in the body.

Finally, one must consider the possibility that classical $\mathrm{ER} \alpha$ or ER $\beta$ may couple to G-protein signaling via an unknown mechanism to mediate rapid estrogen signaling. Navarro et al. [99] have demonstrated by coimmunoprecipitation studies that $\mathrm{ER} \alpha$ interacts with Galphai3 in immortalized GnRH neurons, and that estrogen-induced inhibition of cAMP can be blocked by pertussis toxin, a G-protein signaling inhibitor. Additionally, Kelly and coworkers $[3,66,100]$ have provided evidence of a Galphaqcoupled estrogen receptor that regulates the PLC-PKC-
PKA signaling pathway in hypothalamic neurons and is involved in hypothalamic control of energy homeostasis. Taken as a whole, the above studies provide evidence in specific brain regions that G-protein signaling may be involved in the rapid estrogen effects in the brain, but considerable work is needed to fully understand the mechanisms whereby estrogen couples to and regulate G-protein signaling. Considering the current controversies surrounding the role of GPR30 in estrogen signaling in the brain and other parts of the body, this area should be an important focal point for future research.

\section{Do Scaffold Proteins Help Mediate Rapid Estrogen Signaling?}

It is currently unclear as to how membrane estrogen receptors regulate kinase signaling in the brain. However, work in the last few years has identified estrogen receptor (ER)-interacting scaffold proteins that may serve to link membrane estrogen receptors to kinase signaling pathways via the formation of a signaling complex that includes the ER, ER-interacting protein and various kinases. We will discuss three such ER-interacting proteins MNAR/PELP1 (modulator of nongenomic action of estrogen receptor/proline-, glutamic acid-, and leucinerich protein-1), striatin and p130Cas [101-105]. It should be mentioned that the majority of the work on these proteins has been performed in non-neuronal cells such as breast cancer and endothelial cells; however, where available, we will discuss correlative findings on these scaffold ER-interacting proteins in the brain.

\section{$M N A R / P E L P 1$}

Of all the ER-interacting proteins, we know the most about MNAR/PELP1. Human MNAR/PELP1 was initially cloned and characterized as a novel human coregulator of $\mathrm{ER} \alpha$, with high expression levels present in the brain, testes, and mammary glands [101, 102]. Subsequent work by Brann and coworkers $[103,106]$ cloned the rat and monkey MNAR/PELP1 gene. Figure 2 shows the primary amino acid sequence for rat MNAR/PELP1 (fig. 2a), domain structure deduced from the amino acid sequence (fig. 2b), and RT-PCR expression results for MNAR/PELP1 in various regions of female rat brain (fig. 2c) [103]. The primary structure of rat MNAR/ PELP1 protein was shown to consist of 1,130 amino acids organized into various functionally conserved domains, similar to other species [101-103, 106]. These conserved domains are comprised of various LXXLL, PXXP motifs 
Fig. 2. Primary amino acid sequence of rat MNAR/PELP1 deduced from cDNA cloned into pT7-blue vector (a), and domain/binding motifs organization in the primary structure of the rat MNAR/PELP1 (b). c RT-PCR analysis of MNAR/PELP1 mRNA expression in various tissues from the proestrous female rat. $-\mathrm{RT}=$ Negative control where reverse transcriptase was omitted; +control = cloned rat MNAR/ PELP1 plasmid. From Vadlamudi et al. [101], with permission. maaavlsgpt tgspagapgg pgglsaagsg prlrlllles vsgllqprtg shvapvhppi qwapylpglm cllrlingtag gaqnlsalga lvnlsnahls siktrfeglc llsllvgesp telfqqhcvs wlrsiqqviq sqdspptmel availrdllr yasqlptlfr distnhlpgl ltsllglrpe ceqsalegmk acvtyfprac gflkgklasf flsrldslnp qlqqlacecy srlpslgagf sqglkhtenw eqelhsllts lhsllgslfe etetapvqse gpgvemllsp seddnthvll qlwqrfsgla rclglmlsse fgapvsvpvq eildlicril gisskninll gdgplrlill pslhlealdl lsalilacgg rllrfgalis rllpqvintw stgrdalapg qerpystirt kvyailelwv cvcgasagml qggasgeall thllsdispp adalklcstr gssdgglqsg kpsapkk1k1 dmgealapps qrkgdrnans dvcaaalrgl srtilmcgpl vkeethrrlh dlvlplvmsv qqgevlgssp ynsscerlel yrlllallla psprepppls calkafslgq wedslevssf csealvtcsa lthprvpplq ssgpacptpa pvpppeapss frapafhtpg pmpsigalps pgpvpsagpi ptvgsmssag svpstgpvps rpgppatanh lglavpglvs vpprllpgse nhragsgedp vlapsgtppp sippdetfgg rvprpafvhy dkeeasdvei slesdsddsv vivpeglpsl ppppstppp vaptgpptas ppvpakedse elpatpgplp ppppppppvs gpvtlpppql vpegtpgggg ptameedltv ininssdeee eeeeeeeed edeeedfee eeedeeeyfe eeeeeefee efeeegele eeeeeeee 1 eevedvefgs ageveeggpp pptlppalpp tdspkvqpea epepglllev eepgaedgpg peiaptlape vlpsqeever egesptagpp qelveeessa pptlleegte gggdkvpppp

a etpaqeemet eteasapqgk eqddtaamla dfidcppdde kpppatepds

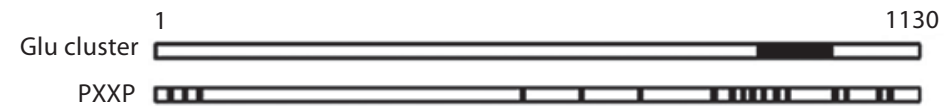

b LXXLL II

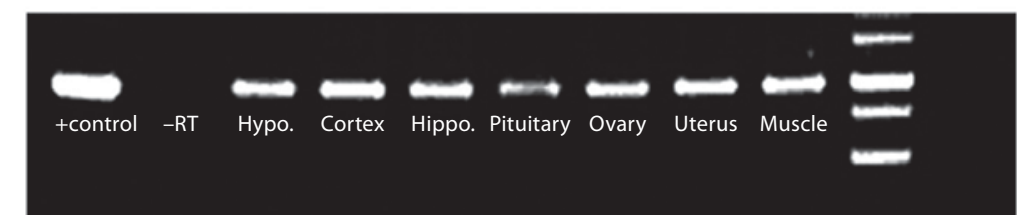

and glutamic acid clusters. The LXXLL motifs have been shown to interact with the AF2 domains of classical steroid receptors, whereas the PXXP domains serve as $\mathrm{SH} 3$ binding sites for Src, PI3K and potentially other SH3 domain proteins, thereby functioning as a scaffold protein to link the estrogen receptor with kinase pathways [101, 102].

MNAR/PELP1 has been shown to be expressed in many regions of the brain that are targets for estrogen action, including the hypothalamus, cerebral cortex, hippocampus, pituitary, and cerebellum (fig. 2) [103, 106]. Furthermore, colocalization studies revealed that MNAR/PELP1 is colocalized with ER $\alpha$ in many regions of the brain [103]. Light- and electron-microscopic studies have demonstrated that MNAR/PELP1 is located at the plasma membrane and in the nucleus of non-neuronal and neuronal cells, supporting its putative nongenomic and genomic roles $[101,103,106]$. Evidence in support of its genomic role in estrogen action has come from studies demonstrating that siRNA to MNAR/PELP1 significantly attenuated estrogen-induced transcription of genes in cells $[101,102,107]$. Likewise, support for a role of MNAR/PELP1 in nongenomic estrogen effects has come from studies demonstrating that estrogen activation of Src-ERK can be blocked by MNAR/PELP1 antisense or siRNA in breast cancer cells [101, 102]. Corollary studies confirming the genomic and nongenomic roles of MNAR/PELP1 in estrogen actions in the brain are underway in our laboratory. Our preliminary work has confirmed that ER- $\alpha$ and MNAR/PELP1 do interact in the brain and that estrogen may enhance this interaction, similar to what has been observed in breast cancer cells [Zhang and Brann, unpubl. obs]. Recent work also suggests that MNAR/PELP1 is phosphorylated and that this phosphorylation promotes estrogen activation of nongenomic signaling pathways, such as PI3K in breast cancer cells [108]. Overall, the above studies support a role for MNAR/PELP1 as an estrogen receptor coactivator and ER-interacting scaffold protein which appears critical for the genomic and nongenomic effects of estrogen. Clearly, while a lot of work has been performed in non-neuronal cells; additional work is needed to understand the role of MNAR/PELP1 in estrogen actions in the brain. 


\section{Striatin}

A second ER protein identified is striatin, a $110-\mathrm{kDa}$ protein which is highly conserved $[104,109,110]$. The protein structure of striatin includes a putative caveolinbinding motif, a coiled-coil structure [111], a $\mathrm{Ca}^{2+}$. calmodulin binding site and a large WD-repeat domain $[109,112-114]$. Work in endothelial cells led to evidence that striatin interacts with $\mathrm{ER} \alpha$, implicating its importance in nongenomic signaling [104]. Along these lines, co-immunoprecipitation experiments revealed an ER $\alpha$ striatin complex formation, with striatin promoting localization of ER $\alpha$ to the membrane [104]. In vascular endothelial cells, striatin has been shown to directly bind to amino acids 183-253 of ER $\alpha$ and to serve as a scaffold for the formation of an ER $\alpha-G$-protein (G $\alpha \mathrm{i})$ complex [104]. Overexpression of a peptide consisting of the striatinbinding domain within ER $\alpha$ disrupts complex formation between ER $\alpha$ and striatin, and blocks estrogen-induced rapid activation of ERKs, Akt, and eNOS, but has no effect on ER-dependent regulation of an estrogen response element-driven reporter plasmid [104]. Little work has been done in any other cell or tissue type on the role of striatin in estrogen actions, including the brain. Interestingly, however, studies have shown abundant localization of striatin to the dendritic spines and somatodendritic regions of the brain $[111,115]$, and thus it appears to act at the postsynaptic level of information processing [109, 116]. Intense immunostaining of striatin has been reported in the dorsal striatum, nucleus accumbens, olfactory tubercle, red nucleus and subthalamic nucleus, while lower levels were detected in the cerebral cortex, amygdala, hippocampus, midbrain and cerebellum [112]. Preliminary data acquired by our lab from the female rat brain verified these results [117]. Moreover, the presence of striatin in a large proportion of efferent neurons has led to the suggestion that it is involved in executive output function [112]. Interestingly, in vitro data from a variety of non-neuronal cells shows that striatin directly binds caveolin-1, a membrane microdomain responsible for the docking of scaffold proteins and the center of signal transduction, thus providing additional evidence of striatin's membrane association $[111,118]$. This is intriguing as several studies have suggested that estrogen receptors may associate with caveoli [118-121]. Obviously, future studies are needed to determine if striatin is colocalized with estrogen receptors in the brain and whether it is modulated by estrogen, as well as to determine what role, if any, it has in mediating estrogen signaling and physiological actions in the brain.
P130Cas

The third ER-interacting protein, a $130-\mathrm{kDa}$, tyrosinephosphorylated p130 protein designated p130Cas (Crkassociated substrate), was identified in 1994 and has been shown to localize both to the membrane and to the nucleus in cells $[105,117,122]$. A full characterization of the localization and distribution of p130Cas in the brain is lacking, but preliminary studies by our laboratory revealed intense immunolocalization of p130Cas in the amygdala, cerebral cortex and striatum of the female rat brain [117]. Analysis of the protein structure of p130Cas revealed a unique $\mathrm{SH} 3$ region in the $\mathrm{N}$-terminal domain [123] as well as a proline-rich domain clustered with tyrosines that functions as SH2-binding motifs [124]. Work in breast cancer cells has shown that $\mathrm{ER} \alpha$ interacts with p130Cas in a multi-molecular complex with Src and PI3K following estrogen administration [105]. Gene knockdown studies suggested an important role for p130Cas in estrogen nongenomic signaling in human breast cancer cells, as siRNA knockdown of p130Cas significantly reduced the ability of estrogen to increase ERK activation [105]. Unfortunately, parallel work in the brain on the role of p130Cas in estrogen signaling has not been conducted to date. However, there is evidence suggesting a role for p130Cas in neurite formation [125] and commissural axon guidance possibly via interactions with GTPase molecules such as Rac and Cdc42 [126-129]. Further research is necessary for the characterization of the functional and physiological roles of p130Cas in the brain and its precise involvement in estrogen signaling.

\section{Conclusions}

In conclusion, there is abundant evidence that estrogen exerts rapid nongenomic effects in the brain to regulate various ion channel, second-messenger and kinase signaling pathways. Figure 3 illustrates the various mechanisms for nongenomic signaling by estrogen that are postulated to occur in neurons. The genomic signaling mechanism is also included in the diagram to illustrate that estrogen can utilize both types of signaling mechanisms to regulate neuronal function. As discussed in the review, an increasing body of work shows that the rapid nongenomic effects of estrogen have a physiologically important role in estrogen-induced neuroprotection, regulation of homeostasis and modulation of synaptic plasticity in the brain. The rapid effects of estrogen in the brain appear to be mediated by a membrane estrogen receptor, although it is not yet entirely clear whether it is $\operatorname{ER} \alpha, \mathrm{ER} \beta$, 


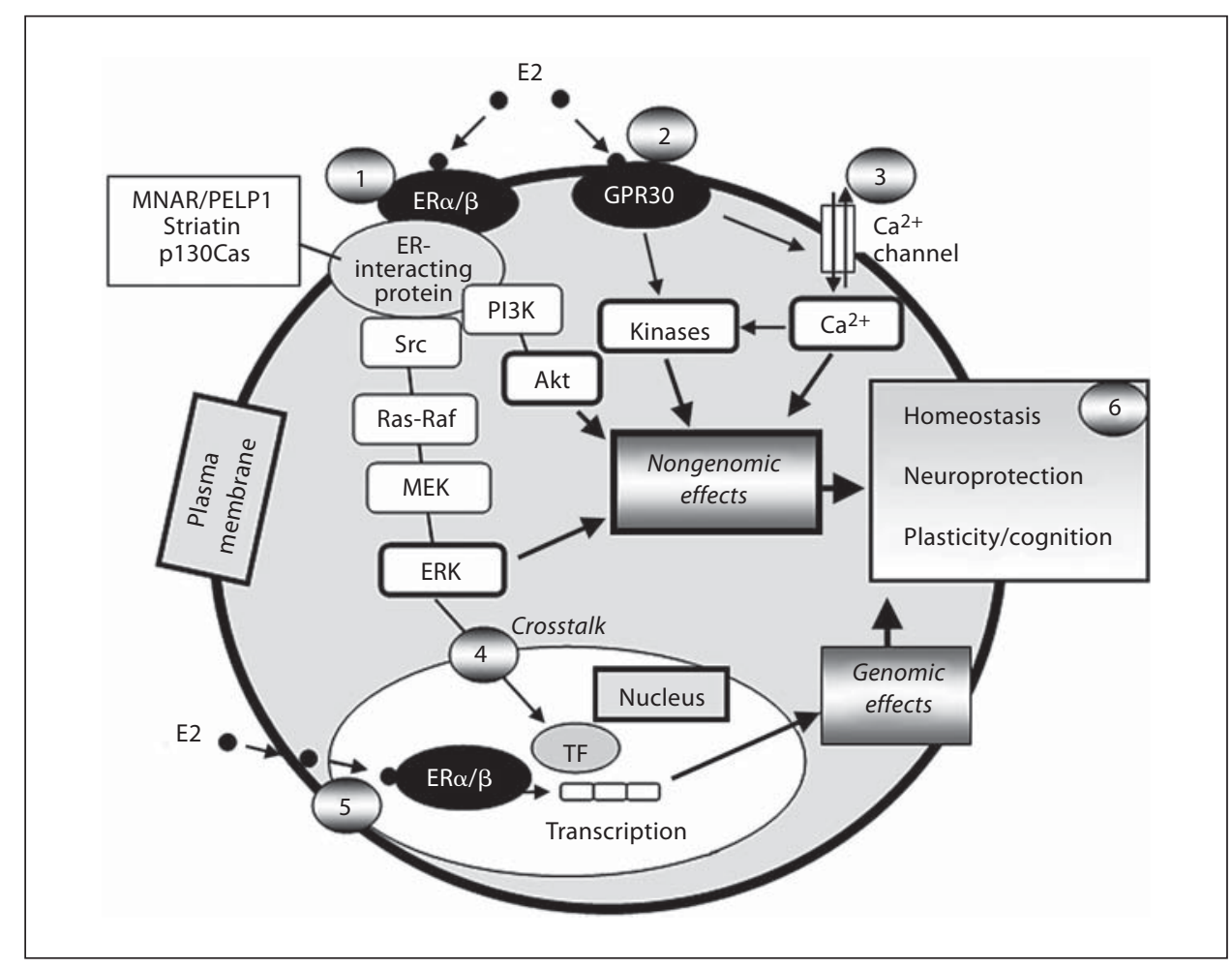

Fig. 3. Summary diagram of potential nongenomic and genomic signaling pathways of estrogen in the brain. (1) Estrogen interaction with classical $E R \alpha / \beta$ in plasma membrane that is in a complex with ER-interacting protein, which facilitates estrogen activation of kinases and subsequent downstream regulation of various cellular proteins and functions. (2) Estrogen interaction with GPR30 in the plasma membrane that leads to activation of kinase and second-messenger signal pathways such as calcium, which exerts multiple downstream effects in the cell. (3) Estrogen, via membrane $\mathrm{ER} \alpha / \beta$ or GPR30-mediated mechanisms, modulates calcium channels to influence intracellular calcium levels, which subsequently regulates activation state of kinases and various other cellular proteins and functions. Estrogen can also modulate calcium release from intracellular calcium stores via kinase regu- lation, as well as regulate other ion channels - such as potassium channels as discussed in the review. (4) Activated phospho-ERK translocates to the nucleus where it can regulate transcription factors such as CREB and Elk1 - and thereby modulate transcription of genes. The actions of phospho-ERK in the nucleus to regulate transcription thus provide a mechanism for crosstalk between the nongenomic and genomic pathways. (5) Classical estrogen genomic signaling via $E R \alpha / \beta$ in nucleus regulates transcription of genes that influence cell functions. (6) Nongenomic signaling effects of estrogen postulated to contribute to homeostasis, neuroprotection and plasticity/cognition actions of estrogen as discussed in the review. (Contributions by genomic effects of estrogen may contribute to these functions as well.)
GPR30, or an as yet unidentified membrane estrogen receptor. Results from ER $\alpha$ and ER $\beta$ knockout models provide some evidence supporting classical estrogen receptors in the mediation of rapid estrogen signaling in the brain. However, these studies show that the role of classical ER $\alpha$ or ER $\beta$ in mediating rapid estrogen signaling in the brain can vary depending on the specific kinase and precise brain region examined, making it difficult to make clear-cut global conclusions and extrapolations. The discovery of GPR30 and its proposal as a putative membrane estrogen receptor has generated much excitement. However, a role for GPR30 in nongenomic estrogen signaling remains controversial, and detailed studies in the brain are lacking. Thus, additional studies are urgently needed to determine the precise role, if any, of GPR30 in estrogen rapid signaling in the brain. Finally, there is growing interest in ER-interacting proteins such as MNAR/PELP1, striatin and p130Cas and the role they may play in mediating estrogen activation of kinase signaling in the brain. These ER-interacting proteins have been shown to couple ER to kinases such as Src and PI3K and to mediate rapid estrogen activation of ERKs and Akt in non-neuronal cells. While the role of these ER-interacting proteins in rapid estrogen signaling in the brain 
has not been examined, MNAR/PELP1 has been shown to be localized in key brain regions that are targets of estrogen action, and it has been shown to be colocalized with ER $\alpha$ in the brain. Striatin and p130Cas are also localized in the brain, but there colocalization with ER $\alpha$ has not been established. For the field to advance, studies using gene knockdown or knockout animal models are needed to establish whether these ER-interacting proteins have a physiologically important role in the signaling and functional effects of estrogen in the brain. In conclusion, while much has been learned in the past decade on nongenomic estrogen signaling in the brain, considerable work remains ahead before we can fully understand the mechanisms that underlie these rapid signaling effects of estrogen, as well as their full physiological significance.

\section{Acknowledgement}

The authors' research is supported by Research Grants from the NIH (NINDS \#NS050730, DWB; NCI CA95681, RKV).

\section{References}

-1 Brann DW, Dhandapandi KM, Wakade C, Mahesh VB, Khan MM: Neurotrophic and neuroprotective actions of estrogen: basic mechanisms and clinical implications. Steroids 2007;72:381-405.

$\checkmark 2$ Petersen SL, Ottem EN, Carpenter CD: Direct and indirect regulation of gonadotropin-releasing hormone neurons by estrogen. Biol Reprod 2003;69:17771-17778.

>3 Kelly MJ, Qiu J, Ronnekleiv OK: Estrogen signaling in the hypothalamus. Vitam Horm 2005;71:123-145.

4 Brann DW, Mills TM, Mahesh VB: Female reproduction: the ovulatory cycle; in Witorsch RJ (ed): Reproductive Toxicology, ed 2. New York, Raven Press, 1995, pp 2344.

$\checkmark 5$ McEwen BS, Alves SE: Estrogen actions in the central nervous system. Endocr Rev 1999;20:279-307.

6 Teede HJ: Sex hormones and the cardiovascular system: effects on arterial function in women. Clin Exp Pharmacol Physiol 2007; 34:672-676.

7 Turner RT, Riggs BL, Spelsberg TC: Skeletal effects of estrogen. Endocr Rev 1994;15:275300 .

$\checkmark 8$ Henderson VW: Estrogen-containing hormone therapy and Alzheimer's disease risk: understanding discrepant inferences from observational and experimental research. Neuroscience 2006;138:1031-1039.

$\checkmark 9$ Sherwin BB: Estrogen and cognitive functioning in women. Endocr Rev 2003;24:133151.

-10 Yang SH, Liu R, Perez EJ, Wang X, Simpkins JW: Estrogens as protectants of the neurovascular unit against ischemic stroke. Curr Drug Targets CNS Neurol Disord 2005;4: 169-177.

11 Dhandapani KM, Brann DW: Protective effects of estrogen and selective estrogen receptor modulators in the brain. Biol Reprod 2002;67:1379-1385.
12 Callier S, Morissette M, Grandbois M, Di Paolo T: Stereospecific prevention by 17 betaestradiol of MPTP-induced dopamine depletion in mice. Synapse 2000;37:245-251.

13 Dluzen D, Horstink M: Estrogen as neuroprotectant of nigrostriatal dopaminergic system: laboratory and clinical studies. Endocrine 2003;21:67-75.

- 14 O'Lone R, Frith MC, Karlsson EK, Hansen $\mathrm{U}$ : Genomic targets of nuclear estrogen receptors. Mol Endocrinol 2004;18:18591875 .

15 Brann DW, Hendry LB, Mahesh VB: emerging diversities in the mechanism of action of steroid hormones. J Steroid Biochem Mol Biol 1955;52:113-133.

16 Manavathi B, Kumar R: Steering estrogen signals from the plasma membrane to the nucleus: two sides of the coin. J Cell Physiol 2006;207:594-604.

$\checkmark 17$ Moriarty K, Kim KH, Bender JR: Minireview: estrogen receptor-mediated rapid signaling. Endocrinology 2006;147:5557-5563.

18 Mhyre AJ, Dorsa DM: Estrogen activates rapid signaling in the brain: role of estrogen receptor alpha and estrogen receptor beta in neurons and glia. Neuroscience 2006;138: 851-858.

19 Boonyaratanakornkit V, Edwards DP: Receptor mechanisms mediating non-genomic actions of sex steroids. Semin Reprod Med 2007;25:139-153.

20 Hall JM, Couse JF, Korach KS: The multifaceted mechanisms of estradiol and estrogen receptor signaling. J Biol Chem 2001;276: 36869-36872.

21 Levin ER: Integration of the extranuclear and nuclear actions of estrogen. Mol Endocrinol 2005;19:1951-1959.

22 Lincoln DW: Unit activity in the hypothalamus, septum and preoptic area of the rat: characteristics of spontaneous activity and the effect of estrogen. J Endocrinol 1967;37: 177-189.
23 Bueno J, Pfaff DW: Single unit recordings in the hypothalamus and preoptic area of estrogen-treated and untreated ovariectomized rats. Brain Res 1976;101:67-78.

24 Yagi K: Changes in firing rates of single preoptic and hypothalamic units following an intravenous administration of estrogen in the castrated female rat. Brain Res 1973;53: 343-352.

25 Dufy B, Partouche C, Poulain D, Dufy-Barbe L, Vincent JD: Effects of estrogen on the electrical activity of identified and unidentified hypothalamic units. Neuroendocrinology 1976;22:38-47.

26 Kelly MJ, Moss RL, Dudley CA: Differential sensitivity of preoptic-septal neurons to $\mathrm{mi}-$ croelectrophoresed estrogen during the estrous cycle. Brain Res 1976;114:152-157.

27 Kelly MJ, Moss RL, Dudley CA: The effects of microelectrophoretically applied estrogen, cortisol and acetylcholine on medial preoptic-septal unit activity throughout the estrous cycle of the female rat. Exp Brain Res 1977;30:53-64.

28 Kelly MJ, Moss RL, Dudley CA. Fawcett CP: The specificity of the response of preopticseptal area neurons to estrogen: $17 \alpha$-estradiol versus $17 \beta$-estradiol and the response of extrahypothalamic neurons. Exp Brain Res 1977;30:43-52.

29 Kelly MJ, Moss RL, Dudley CA: The effects of ovariectomy on the responsiveness of preoptic-septal neurons to microlectrophoresed estrogen. Neuroendocrinology 1978; 25:204-211.

30 Nakekura J, Oomura Y, Minami T, Mizuno $Y$, Fukuda A: Mechanism of the rapid effect of $17 \beta$-estradiol on medial amygdala neurons. Science 1986;232:226-228.

31 Smith S: The effects of estrogen and progesterone on GABA and glutamate responses at extrahypothalmic sites; in Costa E, Paul S: Neurosteroids and Brain Function. New York, Thieme Medical Publishers, 1991, pp 87-94. 
32 Wong M, Moss RL: Long-term and shortterm electrophysiological effects of estrogen on the synaptic properties of hippocampal CA1 neurons. J Neurosci 1992;12:32173225.

-33 Gu Q, Moss RL: 17-beta-Estradiol potentiates kainite-induced currents via activation of the cAMP cascade. J Neurosci 1996;16: 3620-3629.

- 34 Watters JJ, Campbell JS, Cunningham MJ, Krebs EG, Dorsa DM: Rapid membrane effects of steroids in neuroblastoma cells: effects of estrogen on mitogen activated protein kinase signaling cascade and c-fos immediate early gene transcription. Endocrinology 1997;138:4030-4033.

- 35 Singh M, Setalo G Jr, Guan X, Warren M, Toran-Allerand CD: Estrogen-induced activation of mitogen-activated protein kinase in cerebral cortical explants: convergence of estrogen and neurotropin signaling pathways. J Neurosci 1999;19:1179-1188.

- 36 Setalo G Jr, Singh M, Nethrapalli IS, ToranAllerand CD: Protein kinase $\mathrm{C}$ activity is necessary for estrogen-induced ERK phosphorylation in neocortical explants. Neurochem Res 2005;30:779-790.

- 37 Mannella P, Brinton RD: Estrogen receptor protein interaction with phosphatidylinositol 3-kinase leads to activation of phosphorylated Akt and extracellular signal-regulated kinase $1 / 2$ in the same population of cortical neurons: a unified mechanism of estrogen action. J Neurosci 2006;26:94399447.

-38 Dominguez R, Liu R, Baudry M: 17-Beta-estradiol-mediated activation of extracellularsignal regulated kinase, phosphatidylinositol 3-kinase/protein kinase B-Akt and $\mathrm{N}$-methyl-D-aspartate receptor phosphorylation in cortical synaptoneurosomes. J Neurochem 2007;101:232-240.

39 Manthey D, Heck S, Engert S, Behl C: Estrogen induces a rapid secretion of amyloid beta precursor protein via the mitogen-activated protein kinase pathway. Eur J Biochem 2001; 268:4285-4291.

-40 Wu TW, Wang JM, Chen S, Brinton RD: 17Beta-estradiol induced Ca2+ influx via Ltype calcium channels activates the Src/ ERK/cyclic-AMP response element binding protein signal pathway and BCL-2 expression in rat hippocampal neurons: a potential initiation mechanism for estrogen-induced neuroprotection. Neuroscience 2005; 135 : 59-72.

-41 Kuroki Y, Fukushima K, Kanda Y, Mizuno $\mathrm{K}$, Watanabe Y: Putative membrane-bound estrogen receptors possibly stimulate mitogen-activated protein kinase in the rat hippocampus. Eur J Pharmacol 2000;400:205209.

-42 Bryant DN, Bosch MA, Ronnekleiv OK, Dorsa DM: 17-Beta-estradiol rapidly enhances extracellular signal-regulated kinase 2 phosphorylation in the rat brain. Neuroscience 2005; 133:343-352.
43 Honda K, Sawada H, Kihara T, Urushitani M, Nakamizo T, Akaike A, Shimohama S: Phosphatidylinositol-3-kinase mediates neuroprotection by estrogen in cultured cortical neurons. J Neurosci Res 2000;60:321327.

44 Honda K, Shimohama S, Sawada S, Sawada H, Kihara T, Nakamizo T, Shibasaki H, Akailke A: Nongenomic antiapoptotic signal transduction by estrogen in cultured cortical neurons. J Neurosci Res 2001;64:466-475.

45 Wilson ME, Liu Y, Wise PM: Estradiol enhances Akt activation in cortical explant cultures following neuronal injury. Brain Res Mol Brain Res 2002;102:48-54.

-46 Mermelstein PG, Becker JB, Surmeier DJ: Estradiol reduces calcium currents in rat neostriatal neurons via a membrane receptor. J Neurosci 1996;16:595-604.

47 Huang Y, Huang YL, Zhang S, Zhu YC, Yao T: Estradiol acutely attenuates glutamate-induced calcium overload in primarily cultured rat hippocampal neurons through a membrane receptor-dependent mechanism. Brain Res 2004;1026:254-260.

48 Beyer C, Raab H: Nongenomic effects of oestrogen: embryonic mouse midbrain neurones respond with a rapid release of calcium from intracellular stores. Eur J Neurosci 1998;10:255-262.

49 Zhao L, Chen S, Ming Wang J, Brinton RD: 17Beta-estradiol induces $\mathrm{Ca}^{2+}$ influx, dendritic and nuclear $\mathrm{Ca}^{2+}$ rise and subsequent cyclic AMP response element-binding protein activation in hippocampal neurons: a potential initiation mechanism for estrogen neuroprotection. Neuroscience 2005; 132: 299-311.

50 Kelly MJ, Qiu J, Rønnekleiv OK: Estrogen modulation of G-protein-coupled receptor activation of potassium channels in the central nervous system. Ann NY Acad Sci 2003; 1007:6-16

51 Kelly MJ, Lagrange AH, Wagner EJ, Rønnekleiv OK: Rapid effects of estrogen to modulate $G$ protein-coupled receptors via activation of protein kinase $\mathrm{A}$ and protein kinase C pathways. Steroids 1999;64:64-75.

52 Numakawa Y, Matsumoto T, Yokomaku D, Taguchi T, Niki E, Hatanaka H, Kunugi H, Numakawa T: 17Beta-estradiol protects cortical neurons against oxidative stress-induced cell death through reduction in the activity of mitogen-activated protein kinase and in the accumulation of intracellular calcium. Endocrinology 2007;148:627-637.

53 Guerra B, Diaz M, Alonso R, Marin R: Plasma membrane estrogen receptors mediates neuroprotection against beta-amyloid toxicity through activation of Raf-1/MEK/ERK cascade in septal-derived cholinergic SN56 neurons. J Neurochem 2004;91:99-109.
54 Kuroki Y, Fukushima K, Kanda Y, Mizuno $\mathrm{K}$, Watanabe Y: Neuroprotection by estrogen via extracellular signal-regulated kinase against quinolinic acid-induced cell death in the rat hippocampus. Eur J Neurosci 2001; 13:472-476

55 Jover-Mengual T, Zukin RS, Etgen AM: MAPK signaling is critical to estradiol protection of CA1 neurons in global ischemia. Endocrinology 2007;148:1131-1143.

56 Wang R, Zhang QG, Han D, Xu J, Lu Q, Zhang GY: Inhibition of MLK3-MKK4/7JNK1/2 pathway by Akt1 in exogenous estrogen-induced neuroprotection against transient global ischemia by a non-genomic mechanism in male rats. J Neurochem 2006; 99:1543-1554.

57 Beyer C, Karolczak M: estrogenic stimulation of neurite growth in midbrain dopaminergic neurons depends on cAMP/protein kinase A signaling. J Neurosci Res 2000;59: 107-116.

58 Mukai H, et al: Rapid modulation of longterm depression and spinogenesis via synaptic estrogen receptors in hippocampal principal neurons. J Neurochem 2007;100:950967.

59 Khan MM, Dhandapani KM, Wakade C, De Sevilla LM, Mahesh VB, Brann DW: Regulation of synaptic proteins and spine density in the prefrontal and somatosensory cortex by 17b-estradiol: implications for synaptic remodeling in the brain. Program No. 405.12. 2005 Abstract Viewer/Itinerary Planner. Washington, DC: Society for Neuroscience; 2005; online.

60 Glidewell-Kenney C, Hurley LA, Pfaff L, Weiss J, Levine JE, Jameson JL: Nonclassical estrogen receptor alpha signaling mediates negative feedback in the female mouse reproductive axis. Proc Natl Acad Sci USA 2007;104:8173-8177.

-61 McDevitt MA, Glidewell-Kenney C, Weiss J, Chambon P, Jameson JL Levine JE: Estrogen response element-independent estrogen receptor (ER)-alpha signaling does not rescue sexual behavior but restores normal testosterone secretion in male ERalpha knockout mice. Endocrinology 2007;148:5288-5294.

62 Carrer HF, Cambiasso MJ, Gorosito S: Effects of estrogen on neuronal growth and differentiation. J Steroid Biochem Mol Biol 2005;93:319-323.

63 Singo AS, Kito S: Estradiol induces PKA activation through the putative membrane receptor in the living hippocampal neuron. J Neural Transm 2005;112:1469-1473.

64 Beyer C, Raab H: Nongenomic effects of oestrogen: embryonic mouse midbrain neurons respond with a rapid release of calcium from intracellular stores. Eur J Neurosci 1998;10: 255-262.

65 Micevych PE, Chaban V, Ogi J, Dewing P, Lu JK, Sinchak K: Estradiol stimulates progesterone synthesis in hypothalamic astrocyte cultures. Endocrinology 2007;148:782-789. 
66 Qui J, Bosch MA, Tobias SC, Grandy DK, Scanlan TS, Ronnekleiv OK, Kelly MJ: Rapid signaling of estrogen in hypothalamic neurons involves a novel G-protein-coupled estrogen receptor that activates protein kinase C. J Neurosci 2003;23:9529-9540.

67 Stevis PE, Deecher DC, Suhadolnik L, Mallis LM, Frail DE: Differential effects of estradiol and estradiol-BSA conjugates. Endocrinology 1999;140:5455-5458.

-68 Taguchi Y, Koslowski M, Bodenner DL: Binding of estrogen receptor with estrogen conjugated to bovine serum albumin (BSA). Nucl Recept 2004;19:5.

-69 Harrington WR, Kim SH, Funk CC, MadakErdogan Z, Schiff R, Katzenellenbogen JA, Katzenellenbogen BS: Estrogen dendrimer conjugates that preferentially activate extranuclear, nongenomic versus genomic pathways of estrogen action. Mol Endocrinol 2006;20:491-502

-70 Vasudevan N, Pfaff DW: Molecular mechanisms of crosstalk between thyroid hormones and estrogens. Curr Opin Endocrinol Diabetes 2005;12:381-388.

71 Vasudevan N, Pfaff DW: Membrane-initiated actions of estrogens in neuroendocrinology: emerging principles. Endocrine Rev 2007;28:1-19.

-72 Rai D, Frolova A, Frasor J, Carpenter AE, Katzenellenbogen BS: Distinctive actions of membrane-targeted versus nuclear localized estrogen receptors in breast cancer cells. Mol Endocrinol 2005;19:1606-1617.

73 Vasudevan N, Kow LM, Pfaff DW: Early membrane estrogenic effects required for full expression of slower genomic actions in a nerve cell line. Proc Natl Acad Sci USA 2001;98:12267-12271.

74 Kow LM, Pfaff DW: The membrane actions of estrogens can potentiate their lordosis behavior-facilitating genomic actions. Proc Natl Acad Sci USA 2004;101:12354-12357.

-75 Milner TA, McEwen BS, Hayashi S, Li CJ, Reagan LP, Alves SE: Ultrastructural evidence that hippocampal alpha estrogen receptors are located at extranuclear sites. J Comp Neurol 2001;429:355-371.

-76 Milner TA, Ayoola K, Drake CT, Herrick SP, Tabori NE, McEwen BS, Warrier S, Alves SE: Ultrastructural localization of estrogen receptor beta immunoreactvity in the rat hippocampal formation. J Comp Neurol 2005; 491:81-95.

-77 Romeo RD, McCarthy JB, Wang A, Milner TA, McEwen BS: Sex differences in hippocampal estradiol-induced N-methyl-D-aspartic cid binding and ultrastructural localization of estrogen receptor-alpha. Neuroendocrinology 2005;81:391-399.

-78 Marin R, Guerra B, Morales A, Diaz M, Alonso R: An oestrogen membrane receptor participates in estradiol actions for the prevention of amyloid-beta peptide1-40-induced toxicity in septal-derived cholinergic SN56 cells. J Neurochem 2003;85:11801189.
79 Marin R, Guerra B, Morales A, Diaz M, Alonso R: An ICI 182,780-sensitive, membrane-related estrogen receptor contributes to estrogenic neuroprotective actions against amyloid-beta toxicity. Ann NY Acad Sci 2003;1007:108-116.

80 Xu Y, Traystman RJ, Hurn PD, Wang MM: Neurite-localized estrogen receptor-alpha mediates rapid signaling by estrogen. J Neurosci Res 2003;74:1-11.

81 Toran-Allerand CD, Guan X, Maclusky NJ, Horvath TL, Dino S, Singh M, Connolly ES Jr, Nethrapalli IS, Tinnikov AA: ER-X: a novel, plasma membrane-associated, putative estrogen receptor that is regulated during development and afer ischemic brain injury. J Neurosci 2002;22:8391-8401.

82 Acconcia F, Ascenzi P, Fabozzi G, Visca P Marino M: S-pamiltoylation modulates human estrogen receptor-alpha functions. Biochem Biophys Re Communi 2004;316:878883.

83 Acoconcia F, Ascenzi P, Bocedi A, Spisni E, Tomasi V, Trentalance A, Visca P, Marino M palmitoylation-dependent estrogen receptor-a membrane localization: regulation by 17 $\beta$-estradiol. Mol Biol Cell 2005;16:231237.

84 Pedram A, Razandi M, Sainson RC, Kim JK, Hughes CC, Levin ER: A conserved mechanism for steroid receptor translocation to the plasma membrane. J Biol Chem 2007;282: 22278-22288.

85 Chaban VV, Micevych PE: Estrogen receptor-alpha mediates estradiol attenuation of ATP-induced $\mathrm{Ca}^{2+}$ signaling in mouse dorsal root ganglion neurons. J Neurosci Res 2005; 81:3-37.

-86 Abraham IM, Han SK, Todman MG, Korach $\mathrm{KS}$, Herbison AE: estrogen receptor beta mediates rapid estrogen actions on gonadotropin-releasing hormone neurons in vivo. J Neurosci 2003;23:5771-5777.

87 Abraham IM, Todman MG, Koeach KS, Herbison AE: Critical in vivo roles for classical estrogen receptors in rapid estrogen actions on intracellular signaling in mouse brain. Endocrinology 2004;145:3055-3061.

88 Singh M, Setalo G Jr, Guan X, Frail DE, Toran-Allerand CD: Estrogen-induced activation of mitogen-activated protein kinase cascade in the cerebral cortex of estrogen receptor-alpha knock-out mice. J Neurosci 2000;20:1694-1700.

89 Dominguez-Salazar E, Shetty S, Rissman EF: Rapid neural Fos responses to oestradiol in oestrogen receptor alphabeta double knockout mice. J Neuroendocrinol 2006;18:195202.

-90 Carmeci C, Thompson DA, Ring HZ, Francke U, Weigel RJ: Identification of a gene (GPR30) with homology to the G-proteincoupled receptor superfamily associated with estrogen receptor expression in breast cancer. Genomics 1997;45:607-617.
91 Filardo EJ, Quinn JA, Bland KI, Frackelton AR Jr: Estrogen-induced activation of ERK1 and ERK-2 requires G-protein coupled receptor homolog, GPR30, and occurs via transactivation of the epidermal growth factor receptor through release of HB-EGF. Mol Endocrinol 2000;14:1649-1660.

$\checkmark 92$ Revankar CM, Cimino DF, Sklar LA, Arterburn JB, Prossnitz ER: A transmembrane intracellular estrogen receptor mediates rapid cell signaling. Science 2005;307: 1625-1630.

93 Filardo EJ, Thomas P: GPR30: a seventransmembrane-spanning estrogen receptor that triggers EGF release. Trends Endocrinol Metab 2005;16:363-367.

94 Thomas P, Pang Y, Filardo EJ, Dong J: Identity of an estrogen membrane receptor coupled to a $G$ protein in human breast cancer cells. Endocrinology 2005;146:624-632.

95 Khan MM, De Sevilla LM, Hadman M, Brann DW: Cellular and subcellular organization of a novel G-protein coupled estrogen receptor (GPR30) in brain: implication for synaptic functions. Program No. 659.19. 2006 Neuroscience Meeting Planner. Atlanta, Society for Neuroscience, 2006; online.

-96 Funakoshi T, Yanai A, Shinoda K, Kawano MM, Mizukami Y: G protein-coupled receptor 30 is an estrogen receptor in the plasma membrane. Biochem Biophys Res Commun 2006;346:904-910.

97 Pedram A, Razandi M, Levin ER: Nature of functional estrogen receptors at the plasma membrane. Mol Endocrinol 2006;20:19962009.

98 Brailiou E, Dun SL, Brailou GC, Mizou K, Sklar LA, Oprea TI, Prossnitz ER, Dun NJ: distribution and characterization of estrogen receptor $G$ protein-coupled receptor 30 in the rat central nervous system. J Endocrinol 2007;193:311-321.

$\checkmark 99$ Navarro CE, Abdul Saeed S, Murdock C, Martinez-Fuentes AJ, Arora KK, Krsmanovic LZ, Catt KJ: regulation of cyclic adenosine $3^{\prime} 5^{\prime}$-monophosphate signaling and pulsatile neurosecretion by $\mathrm{G}_{\mathrm{i}}$-coupled plasma membrane estrogen receptors in immortalized gonadotropin-releasing hormone neurons. Mol Endocrinol 2003;17: 1792-1804.

100 Ronnekleiv OK, Kelly MJ: Diversity of ovarian steroid signaling in the hypothalamus. Front Neuroendocrinol 2005;26:6584.

101 Vadlamudi RK, Wang RK, Mazumdar A, Kim Y, Shin J, Sahin A, Kumar R: Molecular cloning and characterization of PELP1, a novel human coregulator of estrogen receptor-a. J Biol Chem 2001;276:38272-38279.

102 Wong CW, McNally C, Nickbarg E, Komm BS, Cheskis BJ: Estrogen receptor-interacting protein that modulates its nongenomic activity-crosstalk with Src-Erk phosphorylation cascade. Proc Natl Acad Sci USA 2002;99:14783-14788. 
103 Khan MM, Hadman M, Wakade C, De Sevilla LM, Dhandapani KM, Mahesh VB, Vadlamudi RK, Brann DW: Cloning, expression, and localization of MNAR/PELP1 in rodent brain: colocalization in estrogen receptor-alpha but not in gonadotropin-releasing hormone-positive neurons. Endocrinology 2005; 146:5215-5227.

-104 Lu Q, Pallas DC, Surks HK, Baur WE, Mendelsohn ME, Karas RH: Striatin assembles a membrane signaling complex necessary for rapid, nongenomic activation of endothelial NO synthase by estrogen receptor alpha. Proc Natl Acad Sci USA 2004;101: 17126-17131.

105 Cabodi S, Moro L, Baj G, Smeriglio M, Di Stefano P, Gippone S, Surico N, Silengo L, Turco E, Tarone G, Defilippi P: P130Cas interacts with estrogen receptor alpha and modulates non-genomic estrogen signaling in breast cancer cells. J Cell Sci 2004;117: 1603-1611.

- 106 Khan MM, Hadman M, De Sevilla LM, Mahesh VB, Buccafusco J, Hill WD, Brann WB: Cloning, distribution, and colocalization of MNAR/PELP1 with glucocorticoid receptors in primate and nonprimate brain. Neuroendocrinology 2006;84:317-329.

107 Vadlamudi RK, Kumar R: Functional and biological properties of the nuclear receptor coregulator PELP1/MNAR. Nucl Recept Signal 2007;5:e004.

108 Greger JG, Fursov N, Cooch N, Mclarney S, Freedman LP, Edwards DP, Cheskis BJ: phosphorylation of MNAR promotes estrogen activation of phosphatidylinositol 3-kinase. Mol Cell Biol 2007;27:1904-1913.

- 109 Castets F, Bartoli M, Barnier JV, Baillat G, Salin P, Moqrich A, Bourgeois JP, Denizot F, Rougon G, Calothy G, Monneron A: A novel calmodulin-binding protein, belonging to the WD-repeat family, is localized in dendrites of a subset of CNS neurons. J Cell Biol 1996;134:1051-1062.

-110 Moqrich A, Mattei MG, Bartoli M, Rakitina T, Baillat G, Monneron A, Castets F: Cloning of human striatin cDNA (STRN), gene mapping to 2p22-p21, and preferential expression in brain. Genomics 1998;51:136139.
111 Gaillard S, Bailly Y, Benoist M, Rakitina T, Kessler JP, Fronzaroli-Molinières L, Dargent B, Castets F: Targeting of proteins of the striatin family to dendritic spines: role of the coiled-coil domain. Traffic 2006; 7 : 74-84.

112 Salin P, Kachidian P, Bartoli M, Castets F: Distribution of striatin, a newly identified calmodulin-binding protein in the rat brain: an in situ hybridization and immunocytochemical study. J Comp Neurol 1998;397:41-59.

113 Bartoli M, Monneron A, Ladant D: Interaction of calmodulin with striatin, a WDrepeat protein present in neuronal dendritic spines. J Biol Chem 1998;273:2224822253.

114 Castets F, Rakitina T, Gaillard S, Moqrich A, Mattei MG, Monneron A: Zinedin, SG2NA, and striatin are calmodulin-binding, WD repeat proteins principally expressed in the brain. J Biol Chem 2000;275: 19970-19977.

115 Kachidian P, Vuillet J, Bartoli M, Castets F, Nieoullon A, Kerkerian-Le Goff L: Relationships between striatin-containing neurons and cortical or thalamic afferent fibers in the rat striatum: an ultrastructural study by dual labeling. Neuroscience 1998;85: 111-122.

116 Benoist M, Gaillard S, Castets F: The striatin family: a new signaling platform in dendritic spines. J Physiol Paris 2006;99:146153.

117 Raz L, Khan MM, De Sevilla LM, Brann DW: Expression and distribution of estrogen receptor interacting proteins p130Cas and striatin in female rat brain. Program No. 625.12.2007 Neuroscience Meeting Planner. San Diego, Society for Neuroscience, 2007; online.

118 Razandi M, Oh P, Pedram A, Schnitzer J, Levin ER: ERs associate with and regulate the production of caveolin: implications for signaling and cellular actions. Mol Endocrinol 2002;16:100-115.

119 Gilad LA, Schwartz B: Association of estrogen receptor beta with plasma-membrane caveola components: implication in control of vitamin D receptor. J Mol Endocrinol 2007;38:603-618.

$\checkmark 120$ Li T, Sotgia F, Vuolo MA, Li M, Yang WC Pestell RG, Sparano JA, Lisanti MP: Caveolin-1 mutations in human breast cancer: functional association with estrogen receptor alpha-positive status. Am J Pathol 2006; 168:1998-2013.
121 Evinger AJ 3rd, Levin ER: Requirements for estrogen receptor alpha membrane localization and function. Steroids 2005;70:361363.

122 Sakai R, Iwamatsu A, Hirano N, Ogawa S, Tanaka T, Mano H, Yazaki Y, Hirai H: A novel signaling molecule, p130, forms stable complexes in vivo with v-Crk and v-Src in a tyrosine phosphorylation-dependent manner. EMBO J 1994;13:3748-3756.

123 Wisniewska M, Bossenmaier B, Georges G, Hesse F, Dangl M, Künkele KP, Ioannidis I, Huber R, Engh RA: The 1.1 A resolution crystal structure of the p130cas SH3 domain and ramifications for ligand selectivity. J Mol Biol 2005;347:1005-1014.

-124 Nasertorabi F, Garcia-Guzman M, Briknarová $\mathrm{K}$, Larsen $\mathrm{E}$, Havert ML, Vuori K, Ely KR: Organization of functional domains in the docking protein p130Cas. Biochem Biophys Res Commun 2004;324:993998.

125 Bargon SD, Gunning PW, O’Neill GM: The Cas family docking protein, HEF1, promotes the formation of neurite-like membrane extensions. Biochim Biophys Acta 2005;1746:143-154.

126 Vuori K, Hirai H, Aizawa S, Ruoslahti E: Introduction of p130cas signaling complex formation upon integrin-mediated cell adhesion: a role for Src family kinases. Mol Cell 1996;16:2606-2613.

-127 Liu G, Li W, Gao X, Li X, Jürgensen C, Park HT, Shin NY, Yu J, He ML, Hanks SK, Wu JY, Guan KL, Roa Y: P130 cas is required for netrin signaling and commissural axon guidance. J Neurosci 2007;27:957-968.

128 Modzelewska K, Newman LP, Desai R, Keely PJ: Ack1 mediates Cdc42-dependent cell migration and signaling to p130Cas. J Biol Chem 2006;281:37527-37535.

129 Etienne S, Adamson P, Greenwood J, Strosberg AD, Cazaubon S, Couraud PO: ICAM1 signaling pathways associated with Rho activation in microvascular brain endothelial cells. J Immunol 1998;161:5755-5761. 